\title{
Characterization and androgen-dependence of proteins associated with luminal fluid and spermatozoa in the rat epididymis
}

\author{
D. E. Brooks and S. J. Higgins*
}

\begin{abstract}
Department of Animal Physiology, The University of Adelaide, Waite Agricultural Research Institute, Glen Osmond, South Australia 5064, and *Department of Biochemistry, The University of Leeds, 9 Hyde Terrace, Leeds LS2 9LS, U.K.
\end{abstract}

\begin{abstract}
Summary. The proteins of epididymal luminal fluid and of spermatozoa recovered from different regions of the rat epididymis were examined by polyacrylamide gel electrophoresis under non-denaturing and denaturing conditions. Albumin (A) and four major pre-albumin bands (B-E) were observed in epididymal fluid from the cauda on non-denaturing gels. By comparing the migration of these bands with that of standard globular proteins on denaturing gels, the molecular weight of Bands B and $C$ was estimated to be 16000 , Band D was 30000 and Band E was 32000 . Bands D and E were apparently glycoproteins since they stained with periodic acidSchiff's reagent and were bound by an affinity column of Concanavalin $A$.

The pre-albumin proteins (B-E) were of epididymal origin since they (a) were not detected in blood serum, (b) were not detected in testicular extracts and (c) were still found after ligation of the efferent ducts. From the incorporation of radioactive methionine, Bands $B$ and $C$ were shown to be synthesized in the initial segment and caput. The regional distribution of luminal proteins indicated that protein $\mathrm{D}$ was added in the caput and cauda and protein $E$ in the cauda. This regional origin of luminal proteins was confirmed by the altered protein profiles consequent upon the reduced fluid flow through the epididymis brought about by ligation of the efferent ducts. The androgen-dependence of epididymal protein synthesis was also investigated using radioactive methionine. Castration had little effect on total protein synthesis but resulted in the specific reduction of the synthesis of proteins B and C. Several changes were observed in the relative amounts of specific proteins extracted from spermatozoa from different regions of the epididymis and several of these proteins had molecular weights identical with those in luminal fluid. However, there was no evidence for any substantial binding to spermatozoa of the pre-albumin proteins (B-E) of luminal fluid.
\end{abstract}

\section{Introduction}

As spermatozoa pass through the epididymis they acquire the potential to fertilize eggs. In the rat this is achieved in the caput and corpus epididymidis (Dyson \& Orgebin-Crist, 1973) whilst the cauda epididymidis serves principally as a store for mature spermatozoa before their release at ejaculation. The epididymis provides a specific chemical environment in which these maturational changes take place (Brooks, 1979a). This environment is regulated by androgenic hormones, partly by control of the relative activity of a range of intracellular enzymes (Brooks, 1976, 1978). 
One of the features of the luminal fluid of the epididymis is that it contains a number of unique proteins (Barker \& Amann, 1970, 1971; Alumot, Lensky \& Schindler, 1971; Lavon \& Boursnell, 1971; Lavon, Briggs \& Boursnell, 1973; Amann, Killian \& Benton, 1973; Killian \& Amann, 1973; Staněk \& Dostál, 1974; Huang \& Johnson, 1975; Koskimies \& Kormano, 1975; Schellpfeffer \& Hunter, 1970, 1976; Cameo \& Blaquier, 1976; Lea, Petrusz \& French, 1978; Garberi, Kohane, Cameo \& Blaquier, 1979) which may interact with the spermatozoa suspended in the epididymal fluid. Evidence that some of these proteins do bind to spermatozoa has been provided by Cameo \& Blaquier (1976) and by Lea et al. (1978). Moreover, a protein from seminal plasma which, in conjunction with phosphodiesterase inhibitors, can induce forward progression in immature spermatozoa has been described by Acott \& Hoskins (1978). This protein, which has been termed 'forward motility protein', appears to be of epididymal origin (Brandt, Acott, Johnson \& Hoskins, 1978).

Changes in the properties of the sperm surface during epididymal transit have been well documented. These include alterations in antigenic properties (Johnson \& Hunter, 1972; Barker \& Amann, 1970, 1971; Killian \& Amann, 1973; Schellpfeffer \& Hunter, 1976), in surface charge (Bedford, 1975; Hammerstedt, Keith, Hay, DeLuca \& Amann, 1979), and in lectinbinding (Edelman \& Millette, 1971; Nicolson, Usui, Yanagimachi, Yanagimachi \& Smith, 1977; Fournier-Delpech, Danzo \& Orgebin-Crist, 1977). These reflect, presumably, alterations in the protein composition of the sperm plasma-membrane brought about by the selective addition or removal of proteins, or by the modification of existing proteins. Changes in proteins extracted from spermatozoa recovered from different levels of the epididymis have been described by Lavon, Volcani \& Danon (1971), Fournier-Delpech, Bayard \& Boulard (1973) and Olson \& Hamilton (1978).

In the present study we describe some of the proteins present in epididymal fluid of the rat and the androgenic control of their production and we examine changes in the proteins extracted from spermatozoa in different regions of the epididymis.

\section{Materials and Methods}

\section{Chemicals and incubation media}

Coomassie Brilliant Blue R250, bovine serum albumin (Fraction V), highly polymerized caif thymus DNA (type II), amino acids, acrylamide, $\gamma$-D-galactonolactone, $\alpha$-methyl-D-mannoside, neuraminidase (type V) (EC 3.2.1.18), and the lectins from Ricinus communis (type II), Lens culinaris and Triticum vulgare (wheat germ agglutinin, WGA) were obtained from Sigma Chemical Co. (St. Louis, Missouri, U.S.A.). N,N'-methylene-bisacrylamide (BIS) was from Eastman Kodak Co. (Rochester, New York, U.S.A.) and sodium dodecyl sulphate (SDS) from B.D.H. Chemicals Ltd (Poole, Dorset, U.K.). D-Mannonic acid- $\gamma$-lactone and 2-acetamido-2deoxy-D-gluconolactone were from Koch-Light Laboratories (Colnbrook, Bucks, U.K.). Concanavalin A coupled to Sepharose 4B and cyanogen bromide-activated Sepharose 4B were from Pharmacia (Great Britain) Ltd (London, U.K.). Free lectins were coupled to activated Sepharose by the procedure provided by Pharmacia which is based on the method of Porath \& Axén (1976). L- $\left.{ }^{35} \mathrm{~S}\right]$ Methionine (sp. act. $>600 \mathrm{Ci} / \mathrm{mmol}$ ) was from The Radiochemical Centre (Amersham, Bucks, U.K.). Fuji RX X-ray film was from Fuji Photo Film Co. Ltd (Tokyo, Japan). Krebs-Ringer-phosphate was prepared according to DeLuca (1972) but with reduced calcium. The final composition of the Ringer was $150 \mathrm{mM}-\mathrm{Na}^{+}, 4.8 \mathrm{mM}-\mathrm{K}^{+}, 1.3 \mathrm{MM}-\mathrm{Ca}^{2+}, 1.2$ $\mathrm{mM}-\mathrm{Mg}^{2+}, 129 \mathrm{mM}^{2} \mathrm{Cl}{ }^{-}, 15 \cdot 5 \mathrm{mM}^{2} \mathrm{PO}_{4}{ }^{3-}, 1 \cdot 2 \mathrm{mM}^{-} \mathrm{SO}_{4}{ }^{2-}, 10 \mathrm{~mm}$-glucose.

\section{Animais}

Adult male Sprague-Dawley rats (200-350 g) were obtained from Bantin \& Kingman (North Humberside, U.K.). Food and water were always available, and the lighting was $12 \mathrm{~h}$ 
light $/ 24 \mathrm{~h}$. The procedures for castration and for ligation of the testicular efferent ducts have been described previously (Brooks, 1976).

For most experiments the animals were decapitated and the vascular system was perfused with $0.9 \%(w / v) ~ N a C l$ to clear the reproductive organs of blood. This was achieved by opening the thorax and inserting a needle attached to a cannula into the thoracic aorta in the direction of blood flow. The aorta was closed around the needle with a ligature and after removal of the heart, $0.9 \% \mathrm{NaCl}$ was allowed to pass via the cannula into the aorta whilst blood escaped from the vena cava. When the reproductive tissues had been cleared of blood, the epididymis was dissected out, cleared of adhering adipose tissue and then subdivided into four regions (initial segment, and caput, corpus and cauda epididymidis) as defined by Brooks (1976).

\section{Isolation of proteins from epididymal luminal fluid and spermatozoa}

Epididymal tissue which had been cleared of blood by perfusion was sliced by hand with a razor blade into sections approximately $0.5 \mathrm{~mm}$ thick. The slices were shaken in $10 \mathrm{ml}$ Ringer at $32^{\circ} \mathrm{C}$ for $15 \mathrm{~min}$ to allow the escape of spermatozoa and fluid originally contained within the lumen of the epididymal tubule. The Ringer was then carefully separated from the tissue slices by drawing it off with a Pasteur pipette. This Ringer wash was centrifuged at $400 \mathrm{~g}$ for $10 \mathrm{~min}$ to sediment the spermatozoa. The supernatant, containing the luminal fluid, was retained and the spermatozoa were washed twice more by resuspension and centrifugation in fresh Ringer. The pellet of spermatozoa obtained after the third wash was resuspended in $2 \mathrm{ml}$ ice-cold $0.25 \mathrm{M}$ sucrose, $1.5 \mathrm{~mm}-\mathrm{MgCl}_{2}, 0.1 \%$ Triton $\mathrm{X}-100$, and then sonicated for $15 \mathrm{sec}$ using setting 4 on a Soniprobe (Dawe Instruments, London, U.K.).

The two fractions obtained (i.e. the solution of luminal fluid in Ringer and the sonicate of spermatozoa) were centrifuged at $100000 \mathrm{~g}$ for $1 \mathrm{~h}$ at $2^{\circ} \mathrm{C}$. The proteins present in the supernatant were concentrated in preparation for gel electrophoresis in one of two ways: (1) the

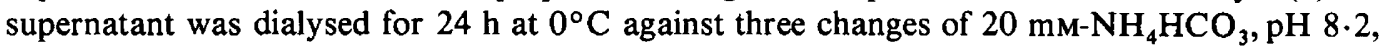
and then freeze-dried and redissolved in $10 \mathrm{mM}$-Tris- $\mathrm{HCl}, \mathrm{pH} \mathrm{7.6;(2)} \mathrm{the} \mathrm{supernatant} \mathrm{was} \mathrm{made}$ $5 \%(\mathrm{w} / \mathrm{v})$ in trichloroacetic acid (TCA) at $0^{\circ} \mathrm{C}$ and after standing in ice for $30 \mathrm{~min}$ the precipitated protein was recovered by centrifugation $(2000 \mathrm{~g}, 10 \mathrm{~min})$, washed three times in ethanol : ether $(1: 1, \mathrm{v} / \mathrm{v})$, dried and dissolved in $30 \mathrm{~mm}-\mathrm{Tris}-\mathrm{HCl}, \mathrm{pH} 6.8,1 \% \mathrm{SDS}, 10 \%$ glycerol.

\section{Incorporation of radioactive methionine into proteins by epididymal tissue in vitro}

Slices of epididymal tissue were prepared and rinsed free of luminal fluid and spermatozoa by two washes in Ringer as described above. The washed slices were blotted on tissue paper moistened with $0.9 \% \mathrm{NaCl}$. Then $25 \mathrm{mg}$ of the blotted tissue were weighed on a torsion balance and added to $1 \mathrm{ml}$ Ringer supplemented with $0.1 \mathrm{~mm}$ of all amino acids except methionine and containing 5-10 $\mu \mathrm{Ci}\left[{ }^{35} \mathrm{~S}\right]$ methionine. The tissue slices were shaken at $32^{\circ} \mathrm{C}$ for $1 \mathrm{~h}$ followed by

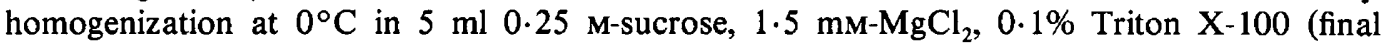
concentrations) using a laboratory blender (Silverson Machines Ltd, Chesham, Bucks, U.K.). The homogenate was centrifuged at $100000 \mathrm{~g}$ for $1 \mathrm{~h}$ at $2^{\circ} \mathrm{C}$. The amount of methionine incorporated into protein was determined in the supernatant fraction whilst DNA was extracted from the precipitate. Other aliquots of the supernatant were processed in preparation for gel electrophoresis as described above.

For estimation of the amount of methionine incorporated into protein, aliquots of supernatant were mixed with $25 \mu \mathrm{l}$ of a solution of bovine serum albumin $(1 \mathrm{mg} / \mathrm{ml})$ and precipitated with 10 volumes of $10 \%$ TCA containing $0.1 \mathrm{mM}-\mathrm{L}-$ methionine. After standing in ice for at least $30 \mathrm{~min}$, the precipitated material in the sample was collected by filtration on 2.5 $\mathrm{cm}$ diameter cellulose acetate filters $(0.45 \mu \mathrm{m}$ pore size, from Oxoid Ltd, Basingstoke, Hants, 
U.K.). The filters were washed through with $5 \%$ TCA containing $0.1 \mathrm{~mm}$-methionine, dried under a lamp and the retained radioactivity was estimated by liquid scintillation spectrometry (Higgins \& Burchell, 1978).

For estimation of DNA, the pellet obtained from the centrifugation of the homogenate at $100000 \mathrm{~g}$ was resuspended at $0^{\circ} \mathrm{C}$ in $5 \mathrm{ml} 0.5 \mathrm{M}-\mathrm{HClO}_{4}$. After $30 \mathrm{~min}$, insoluble material was collected by centrifugation at $2000 \mathrm{~g}$ for $10 \mathrm{~min}$ and this washed pellet was then digested in $1 \mathrm{ml}$ $0.5 \mathrm{M}-\mathrm{HClO}_{4}$ at $70^{\circ} \mathrm{C}$ for $20 \mathrm{~min}$, followed by cooling on ice and re-centrifugation at $2000 \mathrm{~g}$ for $10 \mathrm{~min}$. The supernatant was assayed for solubilized DNA by the method of Burton (1956) using similarly treated calf thymus DNA to construct the standard curve.

\section{Protein determinations}

Protein was determined by the procedure of Lowry, Rosebrough, Farr \& Randall (1951) or of Sedmak \& Grossberg (1977) using bovine serum albumin as the standard.

\section{Chromatography of luminal fluid on affinity columns of lectins}

To limit possible degradation of glycoproteins due to the high glycosidase activity of the epididymis (Conchie, Findlay \& Levvy, 1959), luminal fluid was isolated from the whole epididymis in Ringer containing $10 \mathrm{mM}$-D-mannonic acid- $\gamma$-lactone, $10 \mathrm{mM}-\gamma$-D-galactonolactone and $0.1 \mathrm{~mm}$-2-acetamido-2-deoxy-D-gluconolactone to inhibit the activities of $\alpha$-mannosidase (EC 3.2.1.24), $\beta$-galactosidase (EC 3.2.1.23) and $\beta$-N-acetylglucosaminidase (EC 3.2.1.30) respectively (Conchie et al., 1959). Some aliquots of the isolated luminal fluid (containing about $1 \mathrm{mg}$ protein $/ \mathrm{ml}$ ) were further incubated with $50 \mu \mathrm{g}$ neuraminidase for $1 \mathrm{~h}$ at room temperature in an attempt to remove terminal sialic acid residues and hence to expose new terminal carbohydrate residues.

Samples of luminal fluid $(1 \mathrm{ml})$, with or without neuraminidase treatment, were then diluted to $5 \mathrm{ml}$ with appropriate buffer and applied to columns containing $2 \mathrm{ml}$ Sepharose coupled to approximately $1 \mathrm{mg}$ lectin. The starting buffer for columns containing Ricinus, Lens and WGA

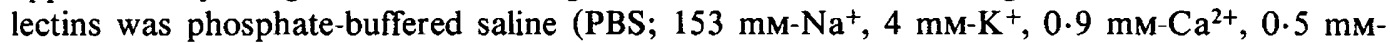
$\mathrm{Mg}^{2+}, 142 \mathrm{mM}^{2} \mathrm{Cl}^{-}, 9.6 \mathrm{mM}^{-} \mathrm{PO}_{4}{ }^{3-}$ ) containing $0.1 \%$ Triton $\mathrm{X}-100$, whereas that for Concanavalin A columns was $20 \mathrm{~mm}$-sodium acetate, $\mathrm{pH} 6.8,0.5 \mathrm{M} \mathrm{NaCl}, 1 \mathrm{~mm}-\mathrm{CaCl}_{2}, 1 \mathrm{mM}^{-}$ $\mathrm{MnCl}_{2}, 1 \mathrm{mM}-\mathrm{MgCl}_{2}, 0 \cdot 1 \%$ Triton X-100. The effluent from the column was cycled twice more through the column and then the column was washed through with $50 \mathrm{ml}$ starting buffer. The column was next eluted with $15 \mathrm{ml}$ starting buffer containing $0.2 \mathrm{M}$ of the appropriate sugar $(\alpha-$ methylmannoside for Lens and Concanavalin A, D-galactose for Ricinus, and $\mathrm{N}$-acetylglucosamine for WGA). The eluate was extensively dialysed against $20 \mathrm{~mm}-\mathrm{NH}_{4} \mathrm{HCO}_{3}$, freezedried, dissolved in $10 \mathrm{~mm}$-Tris- $\mathrm{HCl}, \mathrm{pH} \mathrm{7.6}$, and used for polyacrylamide gel electrophoresis.

\section{Polyacrylamide gel electrophoresis}

Electrophoresis was carried out in slab gels consisting of a $9 \times 15 \times 0.2 \mathrm{~cm}$ resolving gel surmounted by a $1 \mathrm{~cm}$ stacking gel and run at $20 \mathrm{~mA}$ at room temperature until the tracking dye (bromophenol blue) reached the bottom of the gel. Gels were then removed from the apparatus and were stained in $0.1 \%$ Coomassie Brilliant Blue R250 in acetic acid:methanol:water ( $1: 3: 6$, by vol.) and de-stained in the same solution with the dye omitted. For fluorography, gels were impregnated with 2,5-diphenyloxazole (Bonner \& Laskey, 1974), placed in contact with Xray film and kept at $-70^{\circ} \mathrm{C}$ until ready for development. Staining of gels with the periodic acidSchiff (PAS) procedure for glycoproteins was carried out according to Fairbanks, Steck \& Wallach (1971). 
Denaturing gels. Gels were prepared using the buffer systems containing $0 \cdot 1 \%$ SDS as described by Laemmli (1970). The resolving gel consisted of a gradient from 10 to $15 \%$ acrylamide and the proportion of BIS to acrylamide was reduced to $1: 100$ to prevent cracking of the gels during subsequent drying. Samples for electrophoresis were prepared by boiling for $2 \mathrm{~min}$ in $30 \mathrm{~mm}$-Tris- $\mathrm{HCl}, \mathrm{pH} 6.8,5 \% 2$-mercaptoethanol, $1 \% \mathrm{SDS}, 10 \%$ glycerol and $0.002 \%$ bromophenol blue before application to the sample slots. A mixture of proteins of known molecular weight was also run to calibrate the gels ( $\beta$-galactosidase, 130000 ; bovine serum albumin, $68000 ; \gamma$-globulin heavy chain, 50000 ; ovalbumin, $43000 ; \gamma$-globulin light chain, 25000 ; cytochrome c, 12500 ).

Non-denaturing gels. Gels of $7.5 \%$ acrylamide were prepared and run under the discontinuous system at pH 8.4 as described by Maizel (1971).

\section{Results}

\section{Characterization of proteins of epididymal luminal fluid}

Polyacrylamide gel electrophoresis was used to examine the proteins of epididymal luminal fluid. The complex protein spectra revealed under non-denaturing (PI. 1, Fig. 1, lanes 1-4) and denaturing (Pl. 1, Fig. 1, lanes 5-9) conditions were correlated by cutting out some of the protein bands from non-denaturing gels and re-running them under denaturing conditions. Their migration position under these conditions is indicated in PI. 1, Fig. 1. Thus, the particularly prominent Band A (Pl. 1, Fig. 1, lanes 2-4) which co-migrated with albumin in blood serum (Pl. 1, Fig. 1, lane 1) also had the same mobility as albumin (Pl. 1, Fig. 1, lane 9; molecular weight 68000 ) when re-run under denaturing conditions. We therefore presume $B$ and $A$ to consist predominantly of albumin. Nevertheless, Band $A$ was not homogeneous since a component $\left(A^{\prime}\right)$ of lower molecular weight $(20000)$ was revealed by this procedure. Bands D and E consisted of peptides with molecular weights of 30000 and 32000 respectively whilst Bands $B$ and $C$ both had a molecular weight close to 16000 . The migration of Bands $B$ and $C$ on denaturing gels was unaltered by running them in the absence of mercaptoethanol, indicating that neither band normally consists of larger units held together by interchain disulphide linkages.

Bands D and E were apparently glycosylated since they stained with PAS (data not shown) and were selectively retained by an affinity column of Concanavalin A linked to Sepharose 4B (P1. 1, Fig. 2). None of the pre-albumin bands was retained by the other lectin affinity columns (Ricinus, Lens or WGA), nor did binding take place on these columns after treatment with neuraminidase. Some bands which migrated more slowly than albumin were retained by the lectins and, particularly in the case of Ricinus lectin, the banding pattern was altered by treatment with neuraminidase. However, no attempt was made to explore in greater detail the identity of these bands.

\section{Regional differences in proteins of epididymal luminal fluid}

Albumin was particularly noticeable in luminal fluid from all regions of the epididymis ( $\mathrm{Pl} .1$, Fig. 1). In contrast, pronounced regional differences were noted with other proteins. Pre-albumin bands were virtually undetectable in luminal fluid from the initial segment (PI. 1, Fig. 1, lane 2) whereas two prominent pre-albumin bands (B and C) were seen in caput fluid (Pl. 1, Fig. 1, lane 3) with a smaller amount of Band D, which became more prominent in the cauda (Pl. 1, Fig. 1, lane 4). A fourth pre-albumin band (E) became evident in the cauda epididymidis. In addition, other quantitatively less important bands which migrated more slowly than albumin also showed regional variation but these were not studied further.

Regional differences were also revealed by denaturing gels which, as expected, showed a much greater protein complexity (Pl. 1, Fig. 1, lanes 5-8). The most obvious regional differences 
are summarized in Table 1 and some of these differences reflect changes in the pre-albumin bands (B-E) seen on non-denaturing gels. Thus the increase in intensity of the band at 16000 corresponds to the increase of Bands $B$ and $C$, whilst the increase at 30000 would correspond to the increase in Band D. There may well be a greater number of regional changes than we have detected since the bands are probably not homogeneous, and a protein which undergoes regional changes but is coincident with one which does not might not have been detected.

As a further confirmation that the epididymal epithelium regulates the protein composition of luminal fluid by the specific addition and removal of proteins as the fluid passes along the epididymal canal, the regional protein spectra of animals with ligated efferent ducts were compared with those of normal animals (P1. 2, Figs 3 and 4). Ligation of the efferent ducts prevents testicular fluid with its associated proteins from entering the epididymis and this presumably results in a reduced flow of fluid along the epididymis.

After ligation, the pre-albumin Bands $\mathrm{B}$ and $\mathrm{C}$ were considerably reduced in luminal fluid from the cauda (Pl. 2, Fig. 3, lane 3) compared with normal (Pl. 2, Fig. 3, lane 7) and in some preparations were completely absent. This was confirmed by the difference in staining intensity in the cauda at 16000 on denaturing gels (Pl. 2, Fig. 4, lanes 3 and 7). Several other differences

\section{PLATE 1}

Fig. 1. Electrophoresis of blood serum (lanes 1 and 9, $25 \mu \mathrm{g}$ protein) and of epididymal luminal fluid (lanes $2-4,100 \mu \mathrm{g}$ protein; lanes $5-8,50 \mu \mathrm{g}$ protein) under non-denaturing (lanes $1-4$ ) and denaturing (lanes 5-9) conditions. Lanes 2,3 and 4 contained luminal fluid from the initial segment, caput and cauda respectively. The positions of albumin (A) and the 4 pre-albumin bands (B-E) are shown by the letters. Lanes 5, 6, 7 and 8 contained luminal fluid from the initial segment, caput, corpus and cauda respectively. The migration positions of bands A-E isolated from the non-denaturing gel and re-run on the denaturing gel are shown. The molecular weight $\left(\times 10^{-3}\right)$ as a function of migration distance is indicated by the scale at the side of the gel.

Fig. 2. Electrophoresis under non-denaturing conditions of luminal fluid isolated from the whole epididymis in the presence of glycosidase inhibitors and then fractionated on an affinity column of Concanavalin A coupled to Sepharose 4B (see 'Materials and Methods'). Lane 2 contained $100 \mu \mathrm{g}$ protein before application to the affinity column, lane 1 contained $100 \mu \mathrm{g}$ protein not retained by the column and lane 3 contained $50 \mu \mathrm{g}$ protein eluted from the column by $\alpha$ methylmannoside. The positions of albumin (A) and the 4 pre-albumin bands (B-E) are indicated.

\section{PLATE 2}

Fig. 3. Electrophoresis under non-denaturing conditions of luminal fluid from rats with ligated efferent ducts (lanes 1-3) and intact rats (lanes 5-7) and of blood serum (lane 4). Lanes 1 and 5, initial segment; lanes 2 and 6, caput epididymidis; lanes 3 and 7, cauda epididymidis. Luminal fluid samples and blood serum contained 80 and $25 \mu \mathrm{g}$ protein/lane respectively. The positions of albumin (A) and the 4 pre-albumin bands (B-E) are indicated.

Fig. 4. Electrophoresis under denaturing conditions of luminal fluid from rats with ligated efferent ducts (lanes 1-3) and intact rats (lanes 5-7) and of blood serum (lane 4). Lanes 1 and 5, initial segment; lanes 2 and 6, caput epididymidis; lanes 3 and 7 , cauda epididymidis. Luminal fluid samples and blood serum contained 80 and $25 \mu \mathrm{g}$ protein/lane respectively. The molecular weight $\left(\times 10^{-3}\right)$ as a function of migration distance is shown by the scale at the left of the gel and the molecular weight and position of some of the bands which differ between the two conditions are also indicated.

Fig. 5. Fluorograph following electrophoresis under denaturing conditions of proteins from the initial segment of rats with ligated efferent ducts (lane 1) and intact rats (lane 2) after incubation of tissue slices with $\left.{ }^{[35} \mathrm{S}\right]$ methionine. An equal amount (50000 c.p.m.) of radioactive protein was loaded into each lane. The molecular weight $\left(\times 10^{-3}\right)$ as a function of migration distance is shown by the scale at the left of the gel. Differences in labelling intensity at 22000 and 58000 are also indicated. 
PLATE 1
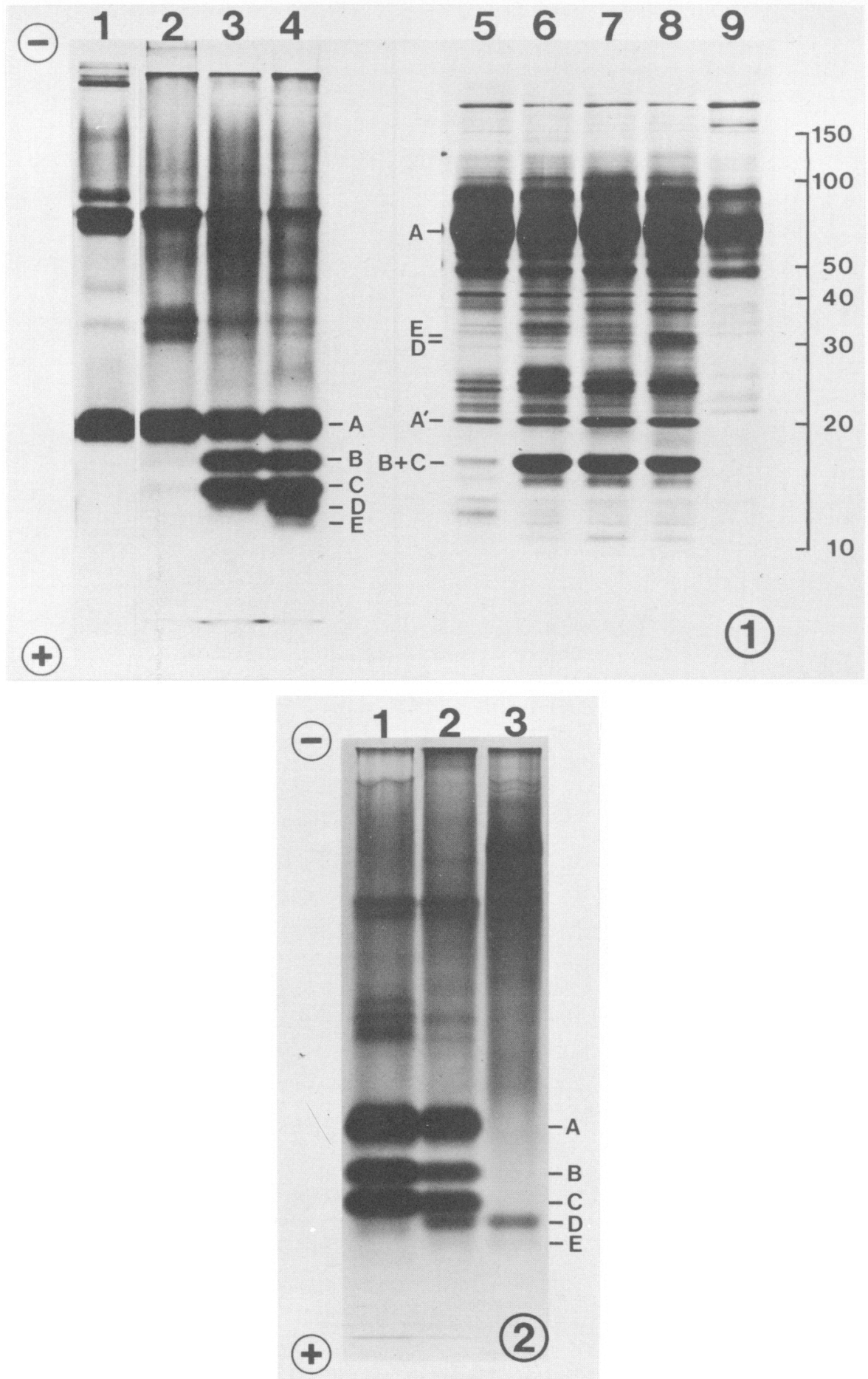
PLATE 2
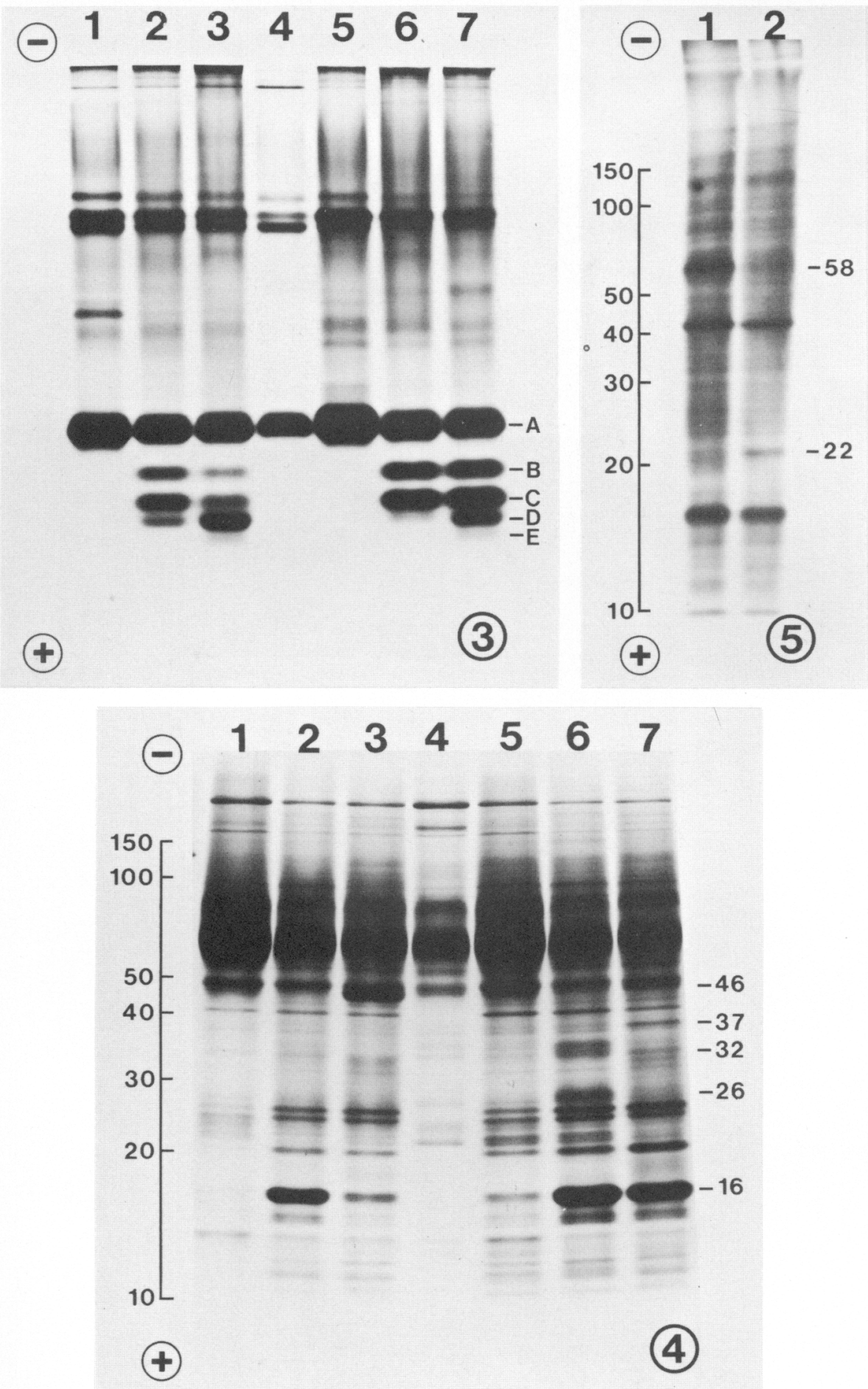
PLATE 3
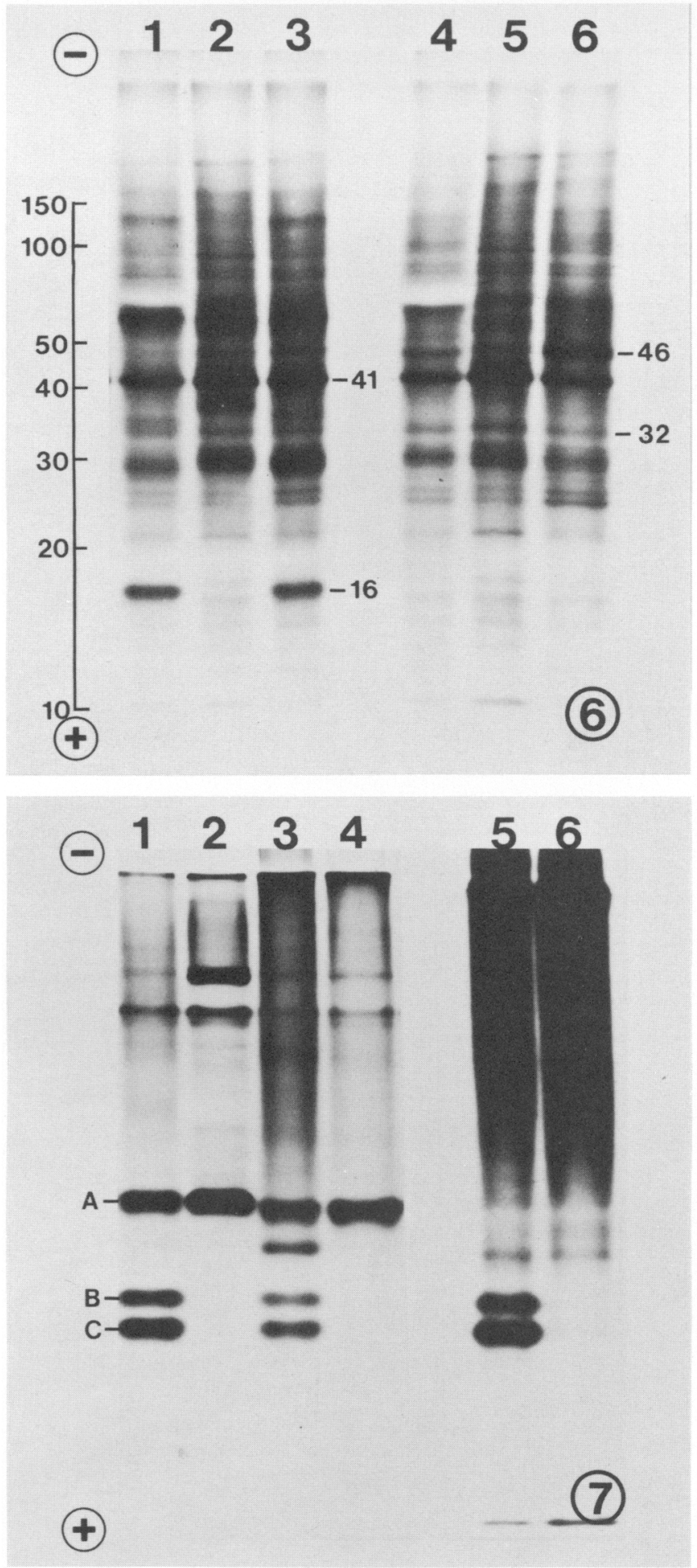
PLATE 4

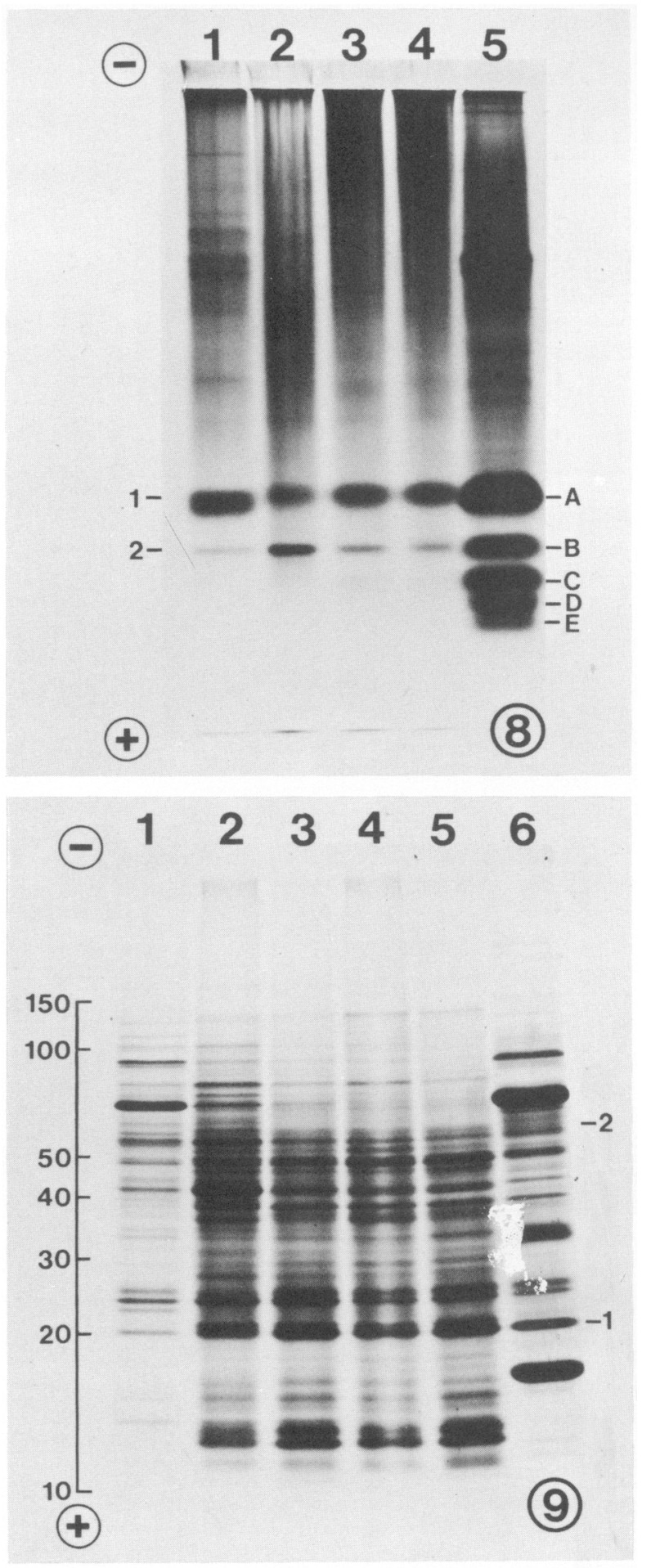


on the denaturing gel were evident for ligated and normal animals. For instance, bands in the range $20000-25000$ were less prominent in the initial segment (Pl. 2, Fig. 4, lanes 1 and 5), as were bands at 26000,32000 and 34000 in the caput (Pl. 2, Fig. 4, lanes 2 and 6) and at 37000 in the cauda (Pl. 2, Fig. 4, lanes 3 and 7). However, in the cauda the band at 46000 was more prominent than in normal animals.

Ligation of the efferent ducts also resulted in a change in the profile of radioactive proteins formed by the initial segment, but not by other regions, during incubation with $\left[{ }^{35} \mathrm{~S}\right]$ methionine. Compared with the initial segment of normal animals, a protein of 58000 was more heavily labelled whilst a protein of 22000 was less intensely labelled (Pl. 2, Fig. 5). At least in the initial segment, therefore, regional changes brought about in the protein spectrum of luminal fluid after ligation may result from reduced flow of fluid along the epididymal duct as well as from an altered synthetic activity of the epithelium.

\section{Regional synthesis of epididymal proteins}

The results of the ligation experiments suggest that pre-albumin Bands $B$ and $C$ are synthesized predominantly by the caput epididymidis. To localize their site of synthesis more precisely the incorporation of $\left[{ }^{35} \mathrm{~S}\right]$ methionine into these proteins was investigated using tissue from different epididymal regions. This confirmed that the cauda (Pl. 3, Fig. 6, lane 4) and corpus (data not shown) do not appear to be involved in the synthesis of Bands $\mathrm{B}$ and $\mathrm{C}$ whereas the caput ( $\mathrm{Pl}$. 3, Fig. 6, lane 1) is particularly active in this respect. These experiments also showed that Bands B and C are synthesized in the initial segment (Pl. 2, Fig. 5, lane 2), even

\section{PLATE 3}

Fig. 6. Fluorograph after electrophoresis under denaturing conditions of proteins from the caput (lanes 1-3) and cauda (lanes 4-6) epididymidis of rats of different androgen status after incubation of tissue slices with ${ }^{33} \mathrm{~S}$ ] methionine. Lanes 1 and 4 , normal rats; lanes 2 and 5, rats castrated for 2 weeks; lanes 5 and 6, rats castrated for 2 weeks followed by 1 week of daily subcutaneous injections of $2 \mathrm{mg}$ testosterone propionate. Each lane contained the same amount (50 000 c.p.m.) of radioactive protein. The molecular weight as a function of migration distance is shown by the scale at the left of the gel. The position and molecular weight $\left(\times 10^{-3}\right)$ of bands discussed in the text are also indicated.

Fig. 7. Electrophoresis under non-denaturing conditions of caput luminal fluid (lane $1 ; 25 \mu \mathrm{g}$ protein), blood serum (lane $2 ; 25 \mu \mathrm{g}$ protein), whole caput epididymidis from a normal rat (lane $3 ; 50 \mu$ p protein) and whole caput epididymidis from a castrated rat (lane 4;50 $\mu$ g protein). Tissue from the caput of normal and castrated rats was incubated with $\left[{ }^{35} \mathrm{~S}\right]$ methionine and an equal amount (50000 c.p.m.) of radioactive protein was loaded into lane 5 (normal caput) and lane 6 (castrated caput) the same gel. This portion of the gel was processed for fluorography. The positions of albumin (A) and the pre-albumin bands (B and C) of luminal fluid are shown.

\section{PLATE 4}

Fig. 8. Electrophoresis under non-denaturing conditions of extracts of testis (lane 1), spermatozoa (lane 2, initial segment; lane 3, caput; lane 4, cauda) and of cauda luminal fluid (lane 5). Each lane contained $100 \mu \mathrm{g}$ of protein. The positions of albumin (A) and the 4 prealbumin bands (B-E) of luminal fluid are indicated in addition to two prominent bands (1 and 2 ) in spermatozoa.

Fig. 9. Elect -phoresis under denaturing conditions of extracts of testis (lane 1, $50 \mu \mathrm{g}$ protein), spermatozoa (lane 2, initial segment; lane 3 , caput; lane 4 , corpus; lane 5 , cauda; $100 \mu$ g protein per lane), ar ff cauda luminal fluid (lane $6 ; 50 \mu \mathrm{g}$ protein). The molecular weight $\left(\times 10^{-3}\right)$ as a function or m:gration distance is indicated by the scale at the left of the gel, as is the migration distance . $\quad r m$ bands 1 and 2 from non-denaturing gels (Fig. 8). 
Table 1. Regional changes in the intensity of staining of proteins (of molecular weights indicated) in luminal fluid and in extracts of spermatozoa obtained from different segments of the epididymis and analysed by polyacrylamide gel electrophoresis under denaturing conditions

\begin{tabular}{|c|c|c|c|}
\hline \multicolumn{2}{|c|}{ Luminal fluid } & \multicolumn{2}{|c|}{ Spermatozoa } \\
\hline Increase & Decrease & Increase & Decrease \\
\hline $\begin{array}{l}37000 \\
* 34000 \\
32000(\mathrm{E})\end{array}$ & & 130000 & 170000 \\
\hline 30000 (D) & & 37000 & 100000 \\
\hline *26000 & & & 90000 \\
\hline $\begin{array}{l}25000 \\
24000\end{array}$ & 22000 & $\begin{array}{l}32000 \\
28000\end{array}$ & 78000 \\
\hline $20000\left(\mathrm{~A}^{\prime}\right)$ & 21000 & $\begin{array}{l}25000 \\
13000\end{array}$ & 74000 \\
\hline $16000(B+C)$ & 12500 & 12500 & $\begin{array}{l}69000 \\
53000\end{array}$ \\
\hline 15000 & & & 27000 \\
\hline
\end{tabular}

The distribution of proteins in luminal fluid (Pl. 1, Fig. 1) and in spermatozoa (Pl. 4, Fig. 8) isolated from different regions of the epididymis was examined on denaturing gels. Where obvious regional changes in staining intensity of particular bands were observed, they were subjectively scored in terms of an increase or a decrease relative to that observed in the initial segment. The letters in parentheses refer to the specific proteins indicated in Pl. 1, Fig. 1.

* Increase from initial segment to caput followed by a decrease in the corpus and cauda.

though these proteins are absent from the luminal fluid of this segment, in intact and in ligated animals (Pl. 2, Fig. 3, lanes 1 and 5).

\section{Androgen-dependence of the synthesis of epididymal proteins}

Since it is well known that androgens have a profound influence on protein synthesis in the male sex accessory glands, an investigation was made of the effect of androgen status on protein synthesis by epididymal tissue. Contrary to expectations, there was little quantitative difference between tissue from normal or castrated animals in terms of the rate of incorporation of ${ }^{[35}$ S $]$ methionine in vitro regardless of the basis used for comparison. Thus the incorporation of radioactivity by caput tissue from castrated animals, expressed as a percentage of that incorporated by tissue from normal animals, was $86 \pm 4$ on the basis of an equal wet weight, $92 \pm 5$ on the basis of an equal amount of soluble protein and $66 \pm 3$ on the basis of an equal amount of DNA (mean \pm s.e.m. of 3 experiments). Furthermore, there were surprisingly few qualitative differences between the two endocrine states as revealed by the spectrum of radioactive proteins seen on denaturing gels (Pl. 3, Fig. 6).

Many radioactive bands were coincident in tissue from normal and castrated rats, including a heavily labelled band at 41000 (Pl. 3, Fig. 6). The major effect of androgen was noted at 16000 in the caput (Pl. 3, Fig. 6, lanes 1-3). This band was heavily labelled in the caput of normal animals (Pl. 3, Fig. 6, lane 1). In contrast, no labelling was observed in this band when tissue from castrated animals was used (Pl. 3, Fig. 6, lane 2). Labelling was restored following the administration of testosterone in vivo (Pl. 3, Fig. 6, lane 3). We have already shown (see above) that this band at 16000 corresponds to the migration position of both the pre-albumin proteins $\mathrm{B}$ and $\mathrm{C}$ of luminal fluid seen on non-denaturing gels (Pl. 3, Fig. 7, lane 1). These 
proteins are present in tissue from normal rats (Pl. 3, Fig. 7, lane 3) but absent in that from castrated rats (P1. 3, Fig. 7, lane 4). Both these proteins are synthesized by the caput of normal animals (Pl. 3, Fig. 7, lane 5) while the androgenic dependence of their synthesis is confirmed by the complete lack of incorporation of radioactive methionine into these bands in the caput of castrated animals (Pl. 3, Fig. 7, lane 6).

In contrast to the caput, there was little difference in the spectrum of radioactive proteins produced in the cauda epididymidis of animals of different androgen status (Pl. 3, Fig. 6, lanes 4-6). However, slight differences in the mobility of bands at 32000 and 46000 suggest that the synthesis of these caudal proteins may be regulated by androgens.

\section{Proteins of spermatozoa}

Spermatozoa mature during epididymal transit by a process which may involve selective protein addition and removal. The spectra of proteins associated with spermatozoa taken from various epididymal regions were therefore studied to see whether any of the luminal proteins already described bind to spermatozoa.

On non-denaturing gels, few discrete bands were visible in extracts of spermatozoa (Pl. 4, Fig. 8). However, two bands were evident which differed in amount depending upon the region of the epididymis from which the spermatozoa were recovered. In some preparations, Band 1 ( $\mathrm{Pl}$. 4, Fig. 8, lanes 2-4) which had a molecular weight of 20000 on denaturing gels (Pl. 4, Fig. 9) increased from the initial segment to the cauda, but in other preparations this change was less obvious. On the other hand, Band 2 (Pl. 4, Fig. 8, lanes 2-4), which migrated as two bands at 60000 and 61000 on denaturing gels (Pl. 4, Fig. 9), decreased in amount from the initial segment to the cauda. Band 2 was also prominent in testicular extracts (P1. 4, Fig. 8, lane 1) and migrated at 60000 on denaturing gels, which suggests that at least one component of Band 2 was already present in spermatozoa emerging from the testis.

As with epididymal fluid, a more complicated spectrum of proteins was evident in sperm extracts on denaturing gels (Pl. 4, Fig. 9) compared with those on non-denaturing gels (Pl. 4, Fig. 8), and additional regional differences were revealed (Table 1). Some of these differences might be accounted for by the binding of proteins from luminal fluid or by the release of proteins from spermatozoa into the luminal fluid. Binding of luminal fluid proteins to spermatozoa is suggested by the presence in spermatozoa from the initial segment of bands which are not obvious in extracts of testis (compare lanes 1 and 2 of Pl. 4, Fig. 9), and by the coincidence of a number of bands in luminal fluid with those in spermatozoa (compare lanes 2-5 with lane 6 of Pl. 4, Fig. 9). There is, for instance, the distinct possibility that sperm Band 1 is identical with the 20000 component ( $\mathrm{A}^{\prime}$, see Pl. 1, Fig. 1) of luminal fluid Band A, since they have identical mobilities on two gel systems. However, there was no evidence that any of the pre-albumin bands of luminal fluid (Pl. 4, Fig. 8, lane 5) became associated in any great quantity with spermatozoa (Pl. 4, Fig. 8 , lanes 2-4). Despite the fact that sperm Band 2 was coincident with pre-albumin Band B on non-denaturing gels, their differing mobilities on denaturing gels (60000 and 61000 compared with 16000 , see above) established that they were not identical.

\section{Discussion}

In the present study albumin and many other serum proteins had mobilities identical with proteins present in epididymal luminal fluid. We assume that these proteins were derived from the epididymal lumen since the vascular system had been perfused before the isolation of luminal fluid, although it is probable that there was some contribution to the luminal fluid fraction by proteins present in the interstitial fluid. Albumin, immunoglobulins and other serum proteins have been detected in the epididymal fiuid of several species (Sedláková, Dostál \& Matoušek, 
1968; Alumot et al., 1971; Amann et al., 1973; Killian \& Amann, 1973; Staněk \& Dostál, 1974; Koskimies \& Kormano, 1975; Huang \& Johnson, 1975). Serum proteins are also present in rete testis fluid of the rat (Koskimies \& Kormano, 1973) and presumably pass into the epididymis by way of the efferent ducts. However, the continued presence of serum proteins in epididymal luminal fluid after ligation of the efferent ducts suggests that they have direct access to the luminal fluid across the epididymal epithelium.

The pattern of proteins seen when cauda luminal fluid was electrophoresed on nondenaturing gels was similar to the pattern described by Koskimies \& Kormano (1975) for epididymal luminal fluid and by Cameo \& Blaquier (1976) for extracts of whole epididymis. Both reports describe prominent pre-albumin bands and Cameo \& Blaquier (1976) adopted the nomenclature of A for the albumin band and B-E for the pre-albumin bands. Since we observed a similar protein profile, we have adopted the same nomenclature but without implying that the proteins are necessarily the same. On denaturing gels, the molecular weight of proteins B and C was 16000 , whilst $\mathrm{D}$ and $\mathrm{E}$ were 30000 and 32000 respectively. These values are similar to those found by Cameo \& Blaquier (1976) using SDS-gel electrophoresis and Garberi et al. (1979) using Sephadex chromatography, with the exception that protein B of Cameo \& Blaquier (1976) was 28000.

We have shown that proteins $B$ and $C$ do not consist of subunits linked by inter-chain disulphide linkages. However, it is possible that they may consist of subunits linked by other forms of bonding. Although the difference between our estimate of the molecular weight of protein B and that of Cameo \& Blaquier (1976) might be explained by the presence of subunits, other data suggest that the two proteins may be quite different entities. For instance, the finding by Cameo \& Blaquier (1976) that the synthesis of protein B was not greatly altered by androgen status contrasts with our findings. Moreover, we were unable to substantiate their report of the presence of protein B (or of protein C) in testicular cytosol.

As judged by the incorporation of radioactive methionine, the synthesis of proteins $\mathrm{B}$ and $\mathrm{C}$ takes place in the initial segment and caput epididymidis. From the relative staining intensity in luminal fluid, protein D appears to be synthesized from the caput to the cauda whereas protein $\mathrm{E}$ only appears in luminal fluid from the cauda. This interpretation of their non-testicular origin, and of the segmental contribution of the epididymis to these luminal proteins, is supported by observations of the segmental distribution of luminal fluid proteins in animals with ligated efferent ducts. When the efferent ducts are ligated testicular fluid is prevented from entering the epididymis and, judging from the altered segmental distribution of small-molecular weight compounds such as carnitine (Brooks, 1979b), the flow of fluid along the epithelium is drastically reduced. In this condition, proteins $\mathrm{B}$ and $\mathrm{C}$ are largely restricted to fluid from the caput, presumably because they are not (as in normal animals) moved distally into the cauda by a flow of fluid.

Androgens are known to affect the relative activities of many intracellular enzymes of the epididymis (Brooks, 1976, 1978, 1979c), which may reflect differences in the rates of synthesis of these enzyme proteins. The present study shows that the synthesis of at least two major epididymal proteins (B and C) are profoundly influenced by androgen status. Other reports (Cameo \& Blaquier, 1976) have shown that androgens regulate the synthesis of major epididymal proteins. However, apart from affecting the synthesis of these secretory proteins, androgens have little effect on the majority of proteins synthesized by the epididymis.

Besides the epididymis, androgens have a pronounced influence on the synthesis of secreted proteins by other accessory sex glands of the rat, such as the ventral prostate and seminal vesicles (Higgins \& Parker, 1980). However, the effects of testosterone are manifest in different ways, e.g. the overall rate of protein synthesis is markedly reduced in the prostate and seminal vesicles after castration (Higgins, Burchell \& Mainwaring, 1976; Higgins \& Burchell, 1978; Parker, Scrace \& Mainwaring, 1978). This contrasts with our experience with the epididymis, but may reflect the much greater proportion of total protein synthesis devoted to the production 
of secreted proteins in the other two tissues. In addition, these tissues differ in the extent to which androgens influence the spectrum of proteins synthesized. Following castration, the synthesis of several major proteins of the ventral prostate is disproportionately decreased (Parker et al., 1978 ) but in the epididymis the synthesis of only two proteins is obviously decreased. In the seminal vesicle, on the other hand, the response to androgens is more general in that the major secretory proteins represent a similar proportion of the total proteins synthesized, regardless of androgen status (Higgins et al., 1976; Higgins \& Burchell, 1978).

The possibility that a number of luminal fluid proteins may become associated with spermatozoa is suggested by (a) the coincident migration of a number of proteins from spermatozoa and luminal fluid (particularly in the range 20000-25000 and at 37000 and 41000 ), (b) the presence of bands in spermatozoa from the initial segment which are not evident in testicular extracts, and (c) increases in band intensity as spermatozoa pass from the initial segment to the cauda. It is possible, for instance, that the protein at 37000 may correspond to the forward motility protein of epididymal fluid described by Brandt et al. (1978) as having a molecular weight of 37500 in its monomeric form. It is also possible that protein D (molecular weight 30000 ) may correspond to the acidic epididymal glycoprotein (AEG) of 33000 purified by Lea et al. (1978). Protein D and AEG are similar in terms of molecular weight, acidic character (as judged from the rate of migration towards the anode on non-denaturing gels), and glycosylation (as judged by PAS staining and by binding to Concanavalin A). However, we were unable to detect the presence of protein $\mathrm{D}$ or any of the other pre-albumin proteins in extracts of spermatozoa after gel electrophoresis; but, using a more sensitive immunological technique, Lea et al. (1978) have shown AEG to be associated with spermatozoa.

Apart from the protein at 37000 described above, a number of other proteins change in relative intensity as spermatozoa pass from the initial segment to the cauda (see Table 1). The decrease in intensity of the pre-albumin Band 2 (molecular weight of 61000 ) suggests that it could be the protein which Fournier-Delpech et al. (1973) found to be lost from spermatozoa in the course of epididymal transit. We were unable, however, to identify on non-denaturing gels the acidic sialoprotein which they describe as being gained by maturing spermatozoa.

It remains to be determined whether the regional changes in protein profile which we have noted on polyacrylamide gels represent alterations of the sperm plasma membrane or alterations of proteins within the spermatozoa. It must also be established which of these changes are essential components of the process of sperm maturation within the epididymis.

D.E.B. was supported by a Royal Society and Nuffield Foundation Commonwealth Bursary and by a grant from the Wellcome Trust. We thank Mr P. Langford for his expert photographic work.

\section{References}

Acott, T.S. \& Hoskins, D.D. (1978) Bovine sperm forward motility protein. Partial purification and characterization. J. biol. Chem. 253, 6744-6750.

Alumot, E., Lensky, Y. \& Schindler, H. (1971) Separation of proteins in the epididymal fluid of the ram. J. Reprod. Fert. 25, 349-353.

Amann, R.P., Killian, G.J. \& Benton, A.W. (1973) Differences in the electrophoretic characteristics of bovine rete testis fluid and plasma from the cauda epididymidis. J. Reprod. Fert. 35, 321-330.

Barker, L.D.S. \& Amann, R.P. (1970) Epididymal physiology. I. Specificity of antisera against bull spermatozoa and reproductive tract fluids. J. Reprod. Fert. 22, 441-452.
Barker, L.D.S. \& Ámann, R.P. (1971) Epididymal physiology. II. Immunofiuorescent analysis of epithelial secretion and absorption, and of bovine sperm maturation. J. Reprod. Fert. 26, 319332.

Bedford, J.M. (1975) Maturation, transport, and fate of spermatozoa in the epididymis. In Handbook of Physiology, Section 7, vol. 5, pp. 303-317. Eds D. W. Hamilton \& R. O. Greep. Am. Physiol. Soc., Washington, D.C.

Bonner, W.M. \& Laskey, R.A. (1974) A film detection method for tritium-labelled proteins and nucleic acids in polyacrylamide gels. Eur. J. Biochem. 46, 83-88. 
Brandt, H., Acott, T.S., Johnson, D.J. \& Hoskins, D.D. (1978) Evidence for epididymal origin of bovine sperm forward motility protein. Biol. Reprod. 19, $830-835$.

Brooks, D.E. (1976) Activity and androgenic control of glycolytic enzymes in the epididymis and epididymal spermatozoa of the rat. Biochem. J. 156, 527537.

Brooks, D.E. (1978) Activity and androgenic control of enzymes associated with the tricarboxylic acid cycle, lipid oxidation and mitochondrial shuttles in the epididymis and epididymal spermatozoa of the rat. Biochem. J. 174, 741-752.

Brooks, D.E. (1979a) Biochemical environment of sperm maturation. In The Spermatozoon, pp. 23-34. Eds D. W. Fawcett \& J. M. Bedford. Urban \& Schwarzenberg, Baltimore.

Brooks, D.E. (1979b) Influence of testicular secretions on tissue weight and on metabolic and enzyme activities in the epididymis of the rat. $J$, Endocr. 82, 305-313.

Brooks, D.E. (1979c) Influence of androgens on the weights of the male accessory reproductive organs and on the activities of mitochondrial enzymes in the epididymis of the rat. J. Endocr. 82, 293-303.

Burton, K. (1956) A study of the conditions and mechanism of the diphenylamine reaction for the colorimetric estimation of deoxyribonucleic acid. Biochem. J. 62, 315-323.

Cameo, M.S. \& Blaquier, J.A. (1976) Androgen-controlled specific proteins in rat epididymis. J. Endocr. 69, 47-55.

Conchie, J., Findlay, J. \& Levvy, G.A. (1959) Mammalian glycosidases. Distribution in the body. Biochem. J. 71, 318-325.

DeLuca, H.F. (1972) In Manometric and Biochemical Techniques, 5th edn, p. 146. Eds W. W. Umbreit, R. H. Burris \& J. F. Stauffer. Burgess Publishing Co., Minneapolis.

Dyson, A.L.M.B. \& Orgebin-Crist, M.-C. (1973) Effect) of hypophysectomy, castration and androgen replacement upon the fertilizing ability of rat epididymal spermatozoa. Endocrinology 93, 391-402.

Edelman, G.M. \& Millette, C.F. (1971) Molecular probes of spermatozoan structure. Proc. natn. Acad. Sci. U.S.A. 68, 2436-2440.

Fairbanks, G., Steck, T.L. \& Wallach, D.F.H. (1971) Electrophoretic analysis of the major polypeptides of the human erythrocyte membrane. Biochemistry, N.Y. 10, 2606-2617.

Fournier-Delpech, S., Bayard, F. \& Boulard, C. (1973) Contribution a l'étude de la maturation du sperme. Etude d'une protéine acide de l'épididyme chez le Rat. Dépendence androgène, relation avec l'acide sialique. C. r. Séanc. Soc. Biol. 167, 19891996.

Fournier-Delpech, S., Danzo, BJ. \& Orgebin-Crist, M.C. (1977) Extraction of concanavalin A affinity material from rat testicular and epididymal spermatozoa. Anals Biol. anim. Biochim. Biophys. 17, 207-213.

Garberi, J.C., Kohane, A.C., Cameo, M.S. \& Blaquier, J.A. (1979) Isolation and characterization of specific rat epididymal proteins. Molec. cell. Endocr. 13, 7382.
Hammerstedt, R.H., Keith, A.D., Hay, D., DeLuca, N. \& Amann, R.P. (1979) Changes in ram sperm membranes during epididymal transit. Arch. Biochem. Biophys. 196, 7-12.

Higgins, S.J. \& Burchell, J.M. (1978) Effects of testosterone on messenger ribonucleic acid and protein synthesis in rat seminal vesicle. Biochem. J. 174, $543-551$.

Higgins, S.J. \& Parker, M.G. (1980) Androgenic regulation of generalised and specific responses in accessory sexual tissues of the male rat. In Biochemical Actions of Hormones, Vol. 7. Ed. G. Litwack. Academic Press, New York.

Higgins, S.J., Burchell, J.M. \& Mainwaring, W.I.P. (1976) Androgen-dependent synthesis of basic secretory proteins by the rat seminal vesicle. Biochem.J. 158, 271-282.

Huang, H.F.S. \& Johnson, A.D. (1975) Comparative study of protein pattern of epididymal plasma of mouse, rat, rabbit and sheep. Comp. Biochem. Physiol. 51B, 337-341.

Johnson, W.L. \& Hunter, A.G. (1972) Immunofluorescent evaluation of the male rabbit reproductive tract for sites of secretion and absorption of seminal antigens. Biol. Reprod. 6, 13-22.

Killian, G.J. \& Amann, R.P. (1973) Immunoelectrophoretic characterization of fluid and sperm entering and leaving the bovine epididymis. Biol. Reprod. 9, 489-499.

Koskimies, A.I. \& Kormano, M. (1973) The proteins in fluids from seminiferous tubules and rete testis of the rat. J. Reprod. Fert. 34, 433-444.

Koskimies, A.I. \& Kormano, M. (1975) Proteins in fluids from different segments of the rat epididymis. $J$. Reprod. Fert. 43, 345-348.

Laemmli, U.K. (1970) Cleavage of structural proteins during the assembly of the head of bacteriophage T4. Nature, Lond. 227, 680-685.

Lavon, U. \& Boursnell, J.C. (1971) Characterization of boar seminal plasma, vesicular secretion and epididymal plasma proteins by gel disc electrophoresis and isoelectric focusing on polyacrylamide. J. Reprod. Fert. 27, 227-232.

Lavon, U., Volcani, R. \& Danon, D. (1971) The proteins of bovine spermatozoa from the caput and cauda epididymidis. J. Reprod. Fert. 24, 219-232.

Lavon, U., Briggs, P.A. \& Boursnell, J.C. (1973) Electrophoresis of protein fractions from boar seminal plasma, vesicular secretion and epididymal plasma. J. Reprod. Fert. 33, 39-51.

Lea, O.A., Petrusz, P. \& French, F.S. (1978) Purification and localization of acidic epididymal glycoprotein (AEG): a sperm coating protein secreted by the rat epididymis. Int. J. Androl., Suppl. 2, 592607.

Lowry, O.H., Rosebrough, N.J., Farr, A.L. \& Randall, R.J. (1951) Protein measurement with the Folin phenol reagent. J. biol. Chem. 193, 265-275.

Maizel, J.V. (1971) Polyacrylamide gel electrophoresis of viral proteins. Meth. Virol. 5, 179-246.

Nicolson, G.L., Usui, N., Yanagimachi, R., Yanagimachi, H. \& Smith, J.R. (1977) Lectin-binding sites on the plasma membranes of rabbit spermatozoa. Changes in surface receptors during epididymal maturation. J. Cell Biol. 74, 950-962. 
Olson, G.E. \& Hamilton, D.W. (1978) Characterization of the surface glycoproteins of rat spermatozoa. Biol. Reprod. 19, 26-35.

Parker, M.G., Scrace, G.T. Mainwaring, W.I.P. (1978) Testosterone regulates the synthesis of major proteins in rat ventral prostate. Biochem. J. 170, 115-121.

Porath, J. \& Axén, R. (1976) Immobilization of enzymes to agar, agarose, and Sephadex supports. Meth. Enzymol. 44, 19-45.

Schellpfeffer, D.A. \& Hunter, A.G. (1970) Electrophoretic and gel filtration behaviour of boar seminal plasma proteins before and after removal of accessory sex glands. J. Reprod. Fert. 23, 291-298.
Schellpfeffer, D.A. \& Hunter, A.G. (1976) Specific proteins of the male reproductive tract. In Regulatory Mechanisms of Male Reproductive Physiology, pp. 115-132. Eds C. H. Spilman, T. J. Lobl \& K. T. Kirton. Excerpta Medica, Amsterdam.

Sedláková, E., Dostál, J. \& Matoušek, J. (1968) Serum albumin in pig epididymis. Comp. Biochem. Physiol. 26, 143-148.

Sedmak, J.J. \& Grossberg, S.E. (1977) A rapid, sensitive, and versatile assay for protein using Coomassie Brilliant Blue G250. Analyt. Biochem. 79, 544-552.

Staněk, R. \& Dostál, J. (1974) Proteins in bull rete testis and cauda epididymidis plasma. Comp. Biochem. Physiol. 48B, 613-618.

Received 1 October 1979 